\title{
Natural diet and feeding habits of the postlarval lobster Homarus americanus
}

\author{
Marie Antonette R. Juinio*, J. Stanley Cobb \\ Department of Zoology, University of Rhode Island, Kingston, Rhode Island 02881, USA
}

\begin{abstract}
Postlarval Homarus americanus were collected from Block Island Sound, Rhode Island, USA, during 5 diel neuston sampling periods in summer 1988 and 1989. The foregut contents of the postlarvae were determined and compared with the relative abundances of potential prey groups in the plankton. Nine taxonomic prey groups were identified in the gut contents $(\mathrm{N}=802)$. The composition of the prey groups and their relative frequencies of occurrence in the guts did not differ with time of day or sampling period. The frequent occurrence of copepods, decapod larvae, fish eggs and insect parts indicates a predominantly carnivorous feeding habit. Furthermore, the disproportionate frequency of occurrence of large copepod species and decapod larvae in the guts relative to their densities in the plankton suggests a preference for larger sized prey. Contrary to expectations, the mean gut fullness and condition of gut contents of individuals at different molt stages were not significantly different. Likewise, there was no significant difference in the incidence of guts with newly ingested prey between postlarvae in the premolt stages and those in the post and intermolt stages. Completely empty guts were rare. In addition, the variability in gut fullness and the condition of gut contents among individuals was high during all sampling periods. These indicate that postlarvae in the field forage successfully throughout the day. However, the significantly higher incidence of newly ingested prey in the guts of postlarval lobsters at night indicates a higher feeding activity during this time.
\end{abstract}

\section{INTRODUCTION}

The American lobster Homarus americanus passes through 4 planktonic instars before settling to the bottom as juveniles. The first 3 larvae are in a mysis form. Metamorphosis into the adult form occurs at the molt from the third to the fourth instar which is called the postlarval stage. Although it resembles the adult, the postlarva swims on the upper meter of the water column before it becomes bottom-seeking (e.g. Herrick 1911, Harding et al. 1987. Cobb et al. 1989). As with the postlarvae of other marine invertebrates with complex life histories, the postlarval period of $H$. americanus is thought to be a period at which benthic recruitment is determined (Caddy \& Campbell 1986, Fogarty \& Idione 1986, Scheltema 1986). Interannual variability in postlarval abundance has been documented for various localities (Scarratt 1973,

\footnotetext{
- Present address: Marine Science Institute, University of the Philippines, Diliman, Quezon City 1101, Philippines
}

review in Fogarty 1983, Cobb unpubl. data) but the mechanisms contributing to the observed variability in postlarval recruitment are not well understood. Food limitation has been suggested to be an important source of mortality during the early planktonic life stages of the American lobster (Phillips \& Sastry 1980, Harding et al. 1983, Castell \& Kean 1986). Basic to an understanding of the importance of food limitation to postlarval recruitment is a knowledge of their feeding ecology.

In contrast to juveniles and adults (see review in Elner \& Campbell 1987), very little is known about the natural diet and feeding habits of postlarval Homarus americanus especially during the planktonic period. Most of the information on the diet of the early planktonic life stages is from laboratory studies undertaken to find suitable diets for the culture of lobster larvae (e.g. Hughes \& Mathiessen 1962, Carlberg \& Van Olst 1976, Eagles et al. 1986). Williams (1907) examined the foreguts of 25 postlarval lobsters held in hatching bags suspended at a dock at Wickford, Rhode Island, USA. 
He found that more guts contained copepods and diatoms than clam meat which was provided as food for these lobsters. The earliest report on the gut content of postlarval lobsters from the wild was by Herrick (1911) who reported echinoderm and mollusk larvae worms, fish eggs and sand in the gut of 2 'lobsterlings' collected from Vineyard Sound (Massachusetts, USA). From observations in the laboratory, he noted that the early pelagic life stages feed raptorially but seemed to lack precise discrimination for their food. In contrast, Harding et al. (1983) examined the foreguts of 16 post. larvae from St. Georges Bay (Newfoundland, Canada) and reported that postlarvae, as well as the third stage, 'preferentially prey on adult female Centropages, large gastropod larvae and zoea and megalops (sic) larvae of Cancer irroratus' relative to the first and second stages. Anectodal accounts in the laboratory and field suggest that while in the plankton, postlarvae are visual predators actively pursuing prey (Williams 1907, Cobb et al. 1983). However, Lavalli \& Barshaw (1989) demonstrated that newly settled postlarvae living in burrows are capable of suspension feeding. It is therefore likely that the postlarval lobster is capable of various feeding mechanisms in both the pelagic and benthic environment.

In this study, the foregut contents of postlarval lobsters collected from Block Island Sound (Rhode Island) during diel neuston sampling were analyzed and compared with the relative abundances of potential prey groups in the plankton. The questions addressed in the present paper are: (1) What is the natural diet of postlarval lobsters in the area, (2) Is there any evidence of preference for any prey group, (3) Is there any periodicity in the feeding activity, and (4) Are there differences in the feeding activity of individuals at different molt stages?

\section{METHODS}

Field collection. Postlarval lobsters were collected from Block Island Sound off Point Judith, Rhode Island $\left(41^{\circ} 21^{\prime} \mathrm{N}, 71^{\circ} 31^{\prime} \mathrm{W}\right)$ using neuston nets $(0.5 \times 1.0 \mathrm{~m}$, $500 \mu \mathrm{m}$ mesh) towed for $10 \mathrm{~min}$ at 1.5 knots. As much as possible, diel sampling was conducted at $3 \mathrm{~h}$ intervals starting at 09:00 $\mathrm{h}$ and continuing to $06: 00 \mathrm{~h}$ the following day (i.e. 8 sampling times) for 3 periods during summer 1988 (June 29-30, July 5-6, July 14-15) and twice in 1989 (June 20-21, June 28-29). In 1989 , diel sampling was conducted from 09:00 h to 09:00 h of the next day. Each of the 09:00 h samples were treated as separate sampling times. Altogether 37 sampling times were conducted during the 5 sampling periods.

Postlarvae were removed immediately from the neuston samples and held in chilled seawater until return to the laboratory. After each neuston tow, a
5 min surface water (top $0.5 \mathrm{~m}$ of the water column) bongo tow was made using $33 \mathrm{~cm}$ diameter paired nets (333 $\mu \mathrm{m}$ mesh) which were fitted with mechanical flowmeters (General Oceanics). In addition, postlarvae were collected from neuston tows made at 09:00 h on 2 days in 1988 and 4 days in 1989. Postlarvae from these additional tows and those collected at 09:00 h during the diel sampling periods (a total of 12 sampling dates) were used to evaluate if there were significant differences in the relative gut fullness and condition of the gut contents among individuals at different molt stages.

In the laboratory, the molt stage of each postlarva was determined by examination of the tissues of the uropod, telson and setae (following the criteria of Sasaki 1984) under the stereomicroscope $(60 \times)$. Individuals from each tow were sorted with respect to molt stage. Both postlarvae and zooplankton samples were initially preserved in $5 \%$ formaldehyde for at least 1 wk and transferred to $70 \%$ isopropyl alcohol prior to storage.

Gut analyses. The foregut of each postlarva was dissected and the contents were examined under the stereomicroscope. Percent gut fullness was visually estimated (empty, <25\%, 26-50\%, 51-75\% and $76-100 \%$ ) and scored 0 to 4 respectively, prior to gut dissection. The prey groups found in each gut were recorded and the prey items were identified to the lowest taxonomic level possible. Prey occurrence in the foregut were recorded on a present or absent basis for each gut. The identity of newly ingested prey items (defined below) was noted. The general condition of the gut contents was scored using the following criteria based on preliminary gut analyses and laboratory experiments. (1) Advanced state of digestion: predominantly fine unrecognizable particles and/or fragments which were not tissue-filled; (2) intermediate state of digestion: presence of almost whole copepods and/or predominantly coarse, recognizable parts (i.e. $>0.5$ mm along the longest axis) with some tissue; (3) newly ingested: presence of whole and intact prey (e.g. copepods, zoea, fish eggs) and recognizable parts (e.g. whole decapod appendages) that were tissue-filled.

Determination of relative abundance of prey groups in the field. Debris, juvenile fish and gelatinous plankton were removed from the bongo tow samples. The sample from each net was split into 2 size fractions: 333 to $1000 \mu \mathrm{m}$ and $>1000 \mu \mathrm{m}$ by washing the samples through a $1000 \mu \mathrm{m}$ mesh sieve. The total wet weight of each size fraction was determined using a Sartorius toploading balance $( \pm 0.1 \mathrm{~g})$ after the sample was drained and blotted dry. Immediately after weighing, the sample was rinsed into a beaker with clean seawater and split to ca 200 to 600 individuals using a Folsom plankton splitter. The copepods, decapod larvae and fish eggs in the subsample were counted. The mean densities (ind. $\mathrm{m}^{-3}$ ) 
of these prey groups in each of the size fractions were estimated for each bongo tow using the paired nets as replicates. These data were used to infer the general patterns of abundance of these potential prey groups in the plankton.

\section{RESULTS}

\section{Foregut contents}

There were 9 taxonomic groups identified in the guts of 802 postlarvae examined during each sampling period (Table 1). In addition, unidentified fibrous bundles and tissue clumps were included as prey groups. Although some guts contained plant material (e.g. filamentous algae and in a few cases diatoms), remains of animal prey items were always found. The composition of the prey groups based on their frequencies of occurrence in the guts was similar among the sampling times (Kendall's coefficients of concordance, $W=0.7$ to 0.9 , $\mathrm{p}<0.005$ ) during each diel sampling period. When all of the samples for each sampling period were pooled (Table 1), the ranking of the prey groups during the 5 sampling periods was also highly similar ( $W=0.70, \mathrm{p}=$ $0.0001)$. These results show that overall, the most common prey groups in the guts of postlarval lobsters were decapod larvae and copepods, followed by fish eggs and insect parts. In comparison, other prey groups were rare and encountered only during 1 or 2 sampling periods (e.g. cladocerans, larvaceans, mysids).

The overall proportions of lobster guts with decapod larvae (range: 42 to $75 \%$ ) and copepods (range: 28 to $72 \%$ ) during the 8 diel sampling times were not significantly different (arcsine-transformed proportions, paired $t$-test, $\mathrm{p}=0.31$ ). However, copepods were en- countered as newly ingested prey more frequently than decapod larvae (arcsine-transformed overall proportions per sampling time, paired t-test, $\mathrm{p}=0.03$ ). The condition of these prey items in the guts indicates that copepods are commonly ingested whole while larger decapod larvae are torn apart prior to ingestion. Although the incidence of insect parts was fairly high (i.e. $26 \%$ of the guts examined), only in 2 guts were insect appendages found filled with tissue. Most of the insect parts were small fragments of various appendages and portions of wings. Likewise, fish eggs (commonly 2 to 4 in a gut) with some tissue (i.e. newly ingested) were rare. In most cases only empty egg cases were found.

The list of crustacean prey items that were identified from the gut contents are shown in Table 2. Among the decapod larvae, crab megalopae were by far the most frequently found. In many cases, megalopae were identified by the presence of a whole cheliped and/or telson. Although it was often impossible to determine the taxa to the species, megalopae and zoea of Cancer spp. were identified in a total of 33 guts. In addition, intact zoea of Ovalipes ocellatus, Pagurus sp. and Callianassa sp. were found. Notably, the remains of more than 2 copepods were found in about $80 \%$ of the total number of guts found to have copepods. In many guts, as many as 6 to 12 individual copepods were found. Calanoid copepods were the most frequently encountered copepod group. The most common species identified were Centropages hamatus and $C$. typicus followed by Acartia spp. and Tortanus discaudatus. As in the case of crab megalopae, calanoid copepods were frequently present during all sampling times and periods. Harpacticoid and cyclopoid copepods and the smaller calanoid copepods (e.g. Paracalanus sp., copepodites) were rare.

Table 1. Frequency of occurrence of the major prey groups found in the guts of postlarval Homarus americanus, sampled during each diel sampling period. The mean ranks (from Kendall's coefficient of concordance) of the prey groups and overall \% frequency of occurrence are also shown $(N=$ total number of samples)

\begin{tabular}{|c|c|c|c|c|c|c|c|}
\hline \multirow{2}{*}{ Prey groups } & \multicolumn{3}{|c|}{1988} & \multicolumn{2}{|c|}{1989} & \multirow{2}{*}{$\begin{array}{l}\text { Mean } \\
\text { rank }\end{array}$} & \multirow{2}{*}{$\begin{array}{c}\text { Overall } \\
\text { frequency } \\
\% \\
(\mathrm{~N}=802)\end{array}$} \\
\hline & $\begin{array}{l}\text { June } 29-30 \\
(N=49)\end{array}$ & $\begin{array}{l}\text { July } 5-6 \\
(N=145)\end{array}$ & $\begin{array}{l}\text { July } 14-15 \\
(N=168)\end{array}$ & $\begin{array}{c}\text { June } 20-21 \\
(N=248)\end{array}$ & $\begin{array}{l}\text { June } 28-29 \\
(\mathrm{~N}=192)\end{array}$ & & \\
\hline Decapod larvae & 36 & 100 & 108 & 147 & 107 & 10.6 & 62.1 \\
\hline Copepods & 31 & 88 & 77 & 176 & 60 & 10.0 & 53.9 \\
\hline Insect parts & 0 & 13 & 17 & 64 & 116 & 7.6 & 26.2 \\
\hline Fish eggs & 6 & 38 & 43 & 7 & 37 & 8.2 & 16.3 \\
\hline Plant matter & 2 & 1 & 1 & 18 & 11 & 5.4 & 4.1 \\
\hline Chaetognaths & 0 & 2 & 5 & 0 & 1 & 4.0 & 1.0 \\
\hline Larvaceans & 7 & 0 & 9 & 0 & 0 & 4.4 & 2.0 \\
\hline Cladocerans & 5 & 0 & 0 & 0 & 0 & 2.8 & 0.6 \\
\hline Mysids & 0 & 1 & 1 & 0 & 0 & 2.6 & 0.2 \\
\hline Fibrous bundles & 2 & 1 & 5 & 3 & 10 & 5.0 & 2.6 \\
\hline Tissue clumps & 1 & 5 & 4 & 1 & 9 & 5.4 & 2.5 \\
\hline
\end{tabular}


Table 2. Crustacean prey items and the total number of guts in which they were found $(\mathrm{N}=302)$ collected during the 5 diel sampling periods in 1988 and 1989. ( $N=$ no. of sampling periods in which the prey item was identified)

\begin{tabular}{|c|c|c|}
\hline Crustacean prey items & $N$ & No. of guts \\
\hline Cladoceran & 1 & 5 \\
\hline \multicolumn{3}{|l|}{ Mysid } \\
\hline Neomysis americana & 2 & 2 \\
\hline \multicolumn{3}{|l|}{ Copepods } \\
\hline \multicolumn{3}{|l|}{ Cyclopoid copepod } \\
\hline Oithona sp. & 2 & 2 \\
\hline \multicolumn{3}{|l|}{ Harpacticoid copepod } \\
\hline Microsetella norvegicus & 1 & 1 \\
\hline \multicolumn{3}{|l|}{ Calanoid copepod } \\
\hline Paracalanus sp. & 1 & 1 \\
\hline Pseudocalanus sp. & 4 & 13 \\
\hline Acartia spp. & 5 & 69 \\
\hline Centropages spp. & 4 & 11 \\
\hline C. hamatus & 5 & 139 \\
\hline C. typicus & 5 & 147 \\
\hline Tortanus discaudatus & 4 & 62 \\
\hline Labidocera aestiva & 3 & 9 \\
\hline Temora longicornis & 4 & 33 \\
\hline Calanus sp. & 4 & 6 \\
\hline Unidentified copepodite & 4 & 17 \\
\hline \multicolumn{3}{|l|}{ Decapod larvae } \\
\hline \multicolumn{3}{|l|}{ Brachyuran larvae } \\
\hline \multicolumn{3}{|l|}{ Cancerspp. } \\
\hline Zoea & 3 & 8 \\
\hline Megalopa & 4 & 25 \\
\hline Ovalipes ocellatus zoea & 2 & 6 \\
\hline Unidentified zoea & 3 & 25 \\
\hline Unidentified megalopa & 5 & 124 \\
\hline \multicolumn{3}{|l|}{ Anomuran larvae } \\
\hline Pagurus sp. zoea & 1 & 1 \\
\hline \multicolumn{3}{|l|}{ Macruran larvae } \\
\hline Callianassa sp. zoea & 3 & 5 \\
\hline Unidentified, shrimp-like & 3 & 10 \\
\hline
\end{tabular}

\section{Gut fullness and condition of gut contents}

Of the 822 postlarval lobsters collected during the 5 diel sampling periods in 1988 and 1989, only 20 individuals had empty guts. Of these, 9 were in molt stage A (early postmolt) ; the remaining were in molt stages $\mathrm{B}$ (postmolt) to $\mathrm{D}_{1}$ (premolt). Furthermore, lobsters with empty guts were collected during different sampling times. Generally, the mean gut fullness during each sampling time was at least $50 \%$ (i.e. scored $>2.0$, Table 3).

The average relative gut fullness and condition of gut contents of postlarvae at different molt stages $[\mathrm{B}=$ 9 individuals, $C$ (intermolt $)=49$, premolt stages $\mathrm{D}_{0}=$ 29 , and $\mathrm{D}_{1}=35$ ], sampled at 09:00 h, during 12 dates in 1988 and 1989, were not significantly different (Kruskal-Wallis 1-way ANOVA, p>0.05). Mean gut fullness was not correlated with the mean condition of the gut contents (Table 3) (Spearman's rank correlation coefficient, $p=0.65)$. Moreover, the variability of these 2 indices was high during each sampling time. The coefficients of variation ranged from 10 to $50 \%$ for gut fullness and 29 to $67 \%$ for the condition of the gut contents. However, there was a significant difference in the mean relative gut fullness among the 8 sampling times (Kruskal-Wallis 1-way ANOVA, $\mathrm{p}=0.03$ ). The mean ranks indicate that the mean gut fullness of postlarval lobsters to be lowest during midnight and early morning (24:00 and 03:00 h). Similar analysis on the mean condition of gut contents showed no significant differences with respect to time. In addition, the prey items in each gut were at different states of digestion. This suggests that the gut is not completely evacuated and feeding occurs at different times of the day.

The overall proportion of guts with newly ingested prey was not significantly different between individuals at molt stages $B$ to $C$ and $D_{0}$ to $D_{1}$ during the 8 sampling times (paired $t$-test on arcsine transformed proportions, $p=0.73$ ). Pooling all individuals regardless of molt stage, the proportion of guts with newly ingested prey was not significantly different among the 8 time periods. However, when the sampling times were grouped into night $(21: 00,24: 00,03: 00 \mathrm{~h})$, day $(09: 00,12: 00,15: 00 \mathrm{~h})$, and dawn/dusk $(06: 00,18: 00 \mathrm{~h})$, there was a significant difference among these time categories (1-way ANOVA on arcsine transformed proportions, $p=0.02$ ) (Fig. 1). The proportion of guts examined with newly ingested prey was significantly higher at night and dawn/dusk than during the day (Scheffe's $t$-test, $\mathrm{p}<0.05$ ). Similarly, the proportion of guts with newly ingested copepods was significantly higher at night. In contrast, there was no significant difference in the proportion of guts with newly ingested decapod larvae among these time categories.

\section{Abundance of potential prey groups}

The most common potential prey groups in the plankton were decapod larvae, copepods and fish eggs. Of these, decapod larvae accounted for most of the total zooplankton biomass. As such, the general trend in total zooplankton biomass (Fig. 2) mirrored the diel pattern of the densities of decapod larvae (Fig. 3a). However, in general, copepods were an order of magnitude more abundant than decapod larvae and fish eggs (Fig. 3). Notably, a significant positive correlation between the total prey density and their frequency of occurrence in the gut was found only for copepods during the sampling period July 5-6, 1988 (Spearman's rank correlation, $p=0.01$ ). Furthermore, there was no significant difference in the total densities of decapod larvae and fish eggs during the day, night and dawn/dusk. On the other hand, copepods 
Table 3. Mean fullness of guts (F, scale: 1 to 4) and condition of gut contents (CG, scale: 1 to 3 ) for each sampling time during each sampling period. The total number of samples for each sampling time is shown in parentheses

\begin{tabular}{|c|c|c|c|c|c|c|c|c|c|c|}
\hline \multirow{3}{*}{$\begin{array}{l}\text { Time } \\
\text { (h) }\end{array}$} & \multicolumn{6}{|c|}{1988} & \multicolumn{4}{|c|}{1989} \\
\hline & \multicolumn{2}{|c|}{ June $29-30$} & \multicolumn{2}{|c|}{ July 5-6 } & \multicolumn{2}{|c|}{ July $14-15$} & \multicolumn{2}{|c|}{ June $20-21$} & \multicolumn{2}{|c|}{ June 28-29 } \\
\hline & $\mathrm{F}$ & $\mathrm{CG}$ & $\mathrm{F}$ & $\mathrm{CG}$ & $\mathrm{F}$ & $\mathrm{CG}$ & $\mathrm{F}$ & $\mathrm{CG}$ & $\mathrm{F}$ & $\mathrm{CG}$ \\
\hline 09:00 & \multicolumn{2}{|c|}{ (13) } & \multicolumn{2}{|c|}{ (12) } & - & - & \multicolumn{2}{|c|}{$(20)$} & \multicolumn{2}{|c|}{ (19) } \\
\hline $12: 00$ & \multicolumn{2}{|c|}{ (9) } & \multicolumn{2}{|c|}{ (29) } & \multicolumn{2}{|c|}{ (27) } & 3.5 & 1.8 & 3.6 & 1.9 \\
\hline $15: 00$ & - & - & \multicolumn{2}{|c|}{ (22) } & 2.8 & 1.8 & \multicolumn{2}{|c|}{ (13) } & \multicolumn{2}{|c|}{ (29) } \\
\hline $18: 00$ & \multicolumn{2}{|c|}{$(20)$} & 3.5 & (14) & \multicolumn{2}{|c|}{ (27) } & 3.8 & 1.5 & \multicolumn{2}{|c|}{ (25) } \\
\hline $21: 00$ & - & - & \multicolumn{2}{|c|}{ (14) } & 3.6 & 1.8 & 3.3 & 1.6 & 3.2 & 1.5 \\
\hline $24: 00$ & - & - & \multicolumn{2}{|c|}{ (26) } & 2.6 & 1.9 & \multicolumn{2}{|c|}{ (37) } & 2.7 & 1.9 \\
\hline 03:00 & - & - & \multicolumn{2}{|c|}{ (15) } & 2.7 & 1.9 & \multicolumn{2}{|c|}{$(47)$} & (23) & 2.0 \\
\hline $06: 00$ & 3.0 & $(7)$ & \multicolumn{2}{|c|}{ (13) } & \multicolumn{2}{|c|}{ (14) } & 2.4 & 1.5 & \multicolumn{2}{|c|}{ (19) } \\
\hline $09: 00^{a}$ & - & - & - & - & - & - & 3.0 & 1.6 & 3.1 & 1.5 \\
\hline
\end{tabular}

were significantly more abundant at night than during the day or the crepuscular period (Scheffe's t-test, $\mathrm{p}<0.05)$. As earlier mentioned, the incidence of newly ingested copepods were also higher during the night.

Two-way analysis of variance on the densities of decapod larvae with respect to the size fractions and sampling time showed significant differences only due to size fraction $(\mathrm{p}=0.03)$. Decapod larvae $>1000 \mu \mathrm{m}$ during all sampling times were significantly more abundant than those 333 to $1000 \mu \mathrm{m}$ in size $(p=0.02$,

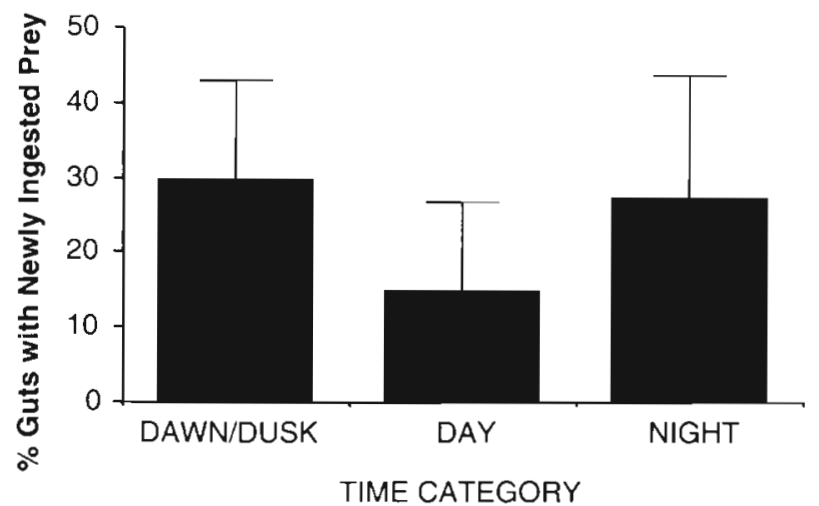

Fig. 1. Homarus americanus. Average frequency of guts with newly ingested prey during dawn/dusk $(06: 00,18: 00 \mathrm{~h})$, day $(09: 00,12: 00,15: 00 \mathrm{~h})$ and night $(21: 00,24: 00,03: 00 \mathrm{~h})$. Standard error bars are shown
Fig. 4a). On the other hand, both the size fraction ( $p=$ $0.109)$ and the time of day ( $p=0.011)$ contributed significantly to the variability in copepod densities. In contrast to decapod larvae, smaller copepods were significantly more abundant than copepods $>1000 \mu \mathrm{m}$ in size. In addition, both smaller decapod larvae and copepods were generally more abundant at night (Fig. 4). There was no significant differences with

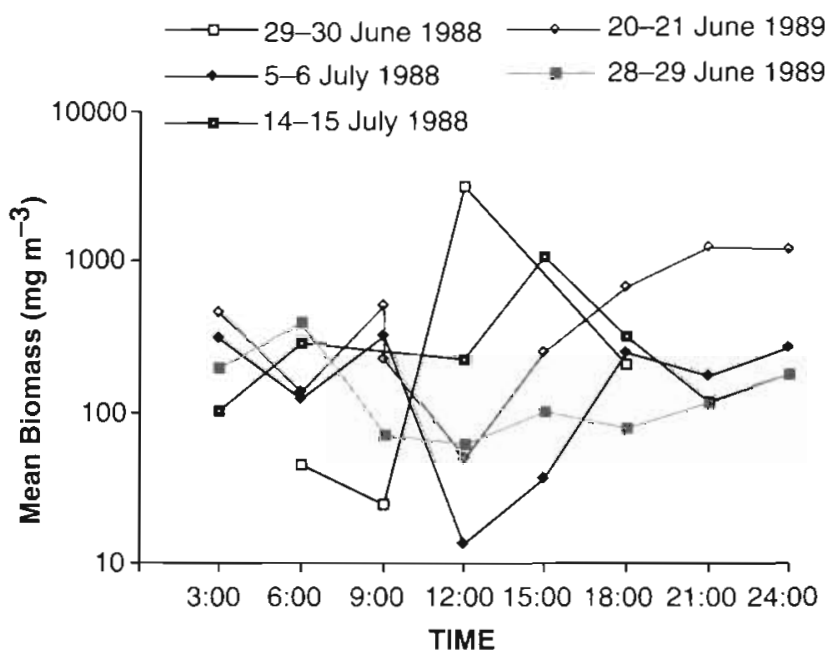

Fig. 2. Mean total biomass ( $\mathrm{mg}$ wet wt $\mathrm{m}^{-3}$ ) of zooplankton sampled from the bongo tows per sampling time during the diel sampling periods in 1988 and 1989 

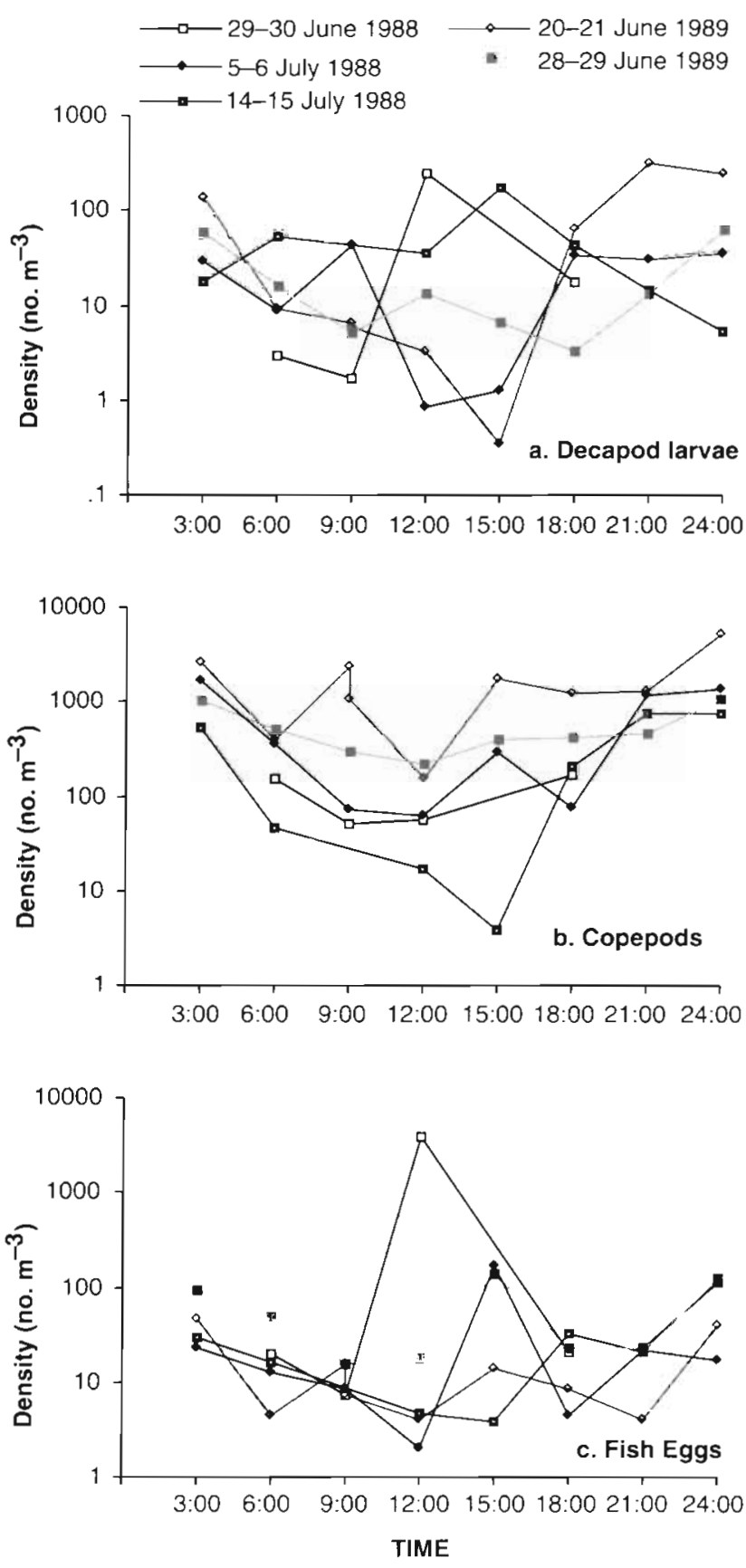

Fig. 3. Mean total densities (ind. $\mathrm{m}^{-3}$ ) of (a) decapod larvae, (b) copepods and (c) fish eggs from the bongo tows per sampling time during the diel sampling periods in 1988 and 1989

respect to either size fraction or sampling time for fish eggs. Interestingly, large decapod larvae, particularly crab megalopae (1.2 to $1.5 \mathrm{~mm}$ total body length) were very frequently found in the gut contents (Table 2). Moreover, despite the greater abundance of smaller copepods especially at night, adult and larger calanoid copepods like Centropages spp. (0.9 to $1.35 \mathrm{~mm}$ body length) and Tortanus discaudatus (1.75 to $2.25 \mathrm{~mm}$
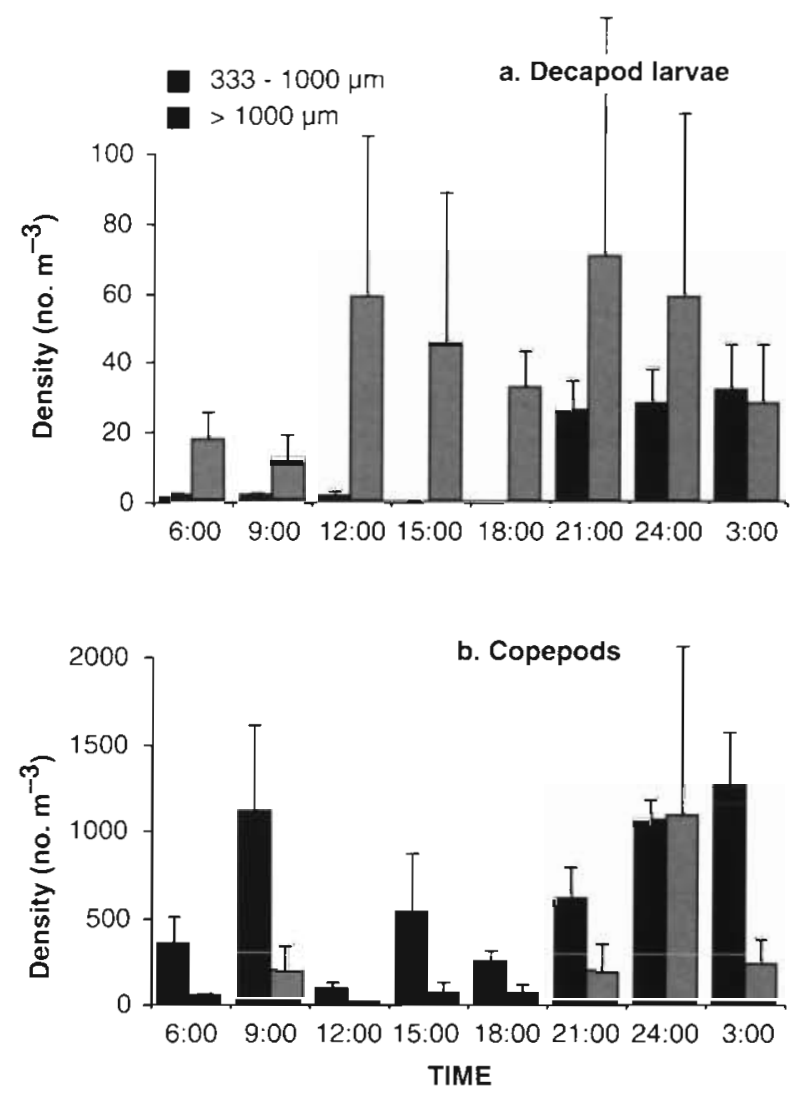

Fig. 4. Mean densities (ind. $\mathrm{m}^{-3}$ ) of (a) decapod larvae and (b) copepods in the $>1000 \mu \mathrm{m}$ and $333-1000 \mu \mathrm{m}$ size fractions from the bongo tows per sampling time during the 5 diel sampling periods in 1988 and 1989. Standard error bars are shown

body length) were the predominant calanoid copepods identified in the guts. These results strongly indicate preference of postlarval lobsters for larger sized prey.

\section{DISCUSSION}

\section{Natural diet}

The prey groups found in the foregut of postlarval lobsters indicate a predominantly carnivorous food habit. This is consistent with earlier reports of other workers (i.e. Williams 1907, Herrick 1911, Harding et al. 1983). The large number of postlarvae examined in this study allowed a quantitative assessment of the relative importance of different prey groups in the diet of lobster postlarvae. We recognize that the frequency of occurrence by itself is by no means an adequate indicator of the relative importance of a prey item (see Hyslop 1980 for a general review of the inherent limitations of gut content analyses). Because it is based on the presence or absence of prey groups in each gut, the frequency of occurrence does not take into account 
the number of individuals for each prey group. Unfortunately, the number of individuals could not always be estimated. This is especially true for decapod larvae of which only the remains of appendages were often recognized. Another measure commonly used together with the frequency of occurrence to evaluate the relative importance of the prey found in the stomachs of crustaceans is the volumetric contribution of the various prey groups in each gut (e.g. Carter \& Steele 1982, Elner \& Campbell 1987 - juvenile and adult lobsters $_{i}$ Haefer 1990 - crabs). Because of the small size of the foregut of postlarval lobsters, approximating relative volumes of various prey groups was impractical. Due to these limitations it was not possible to assess whether copepods are more important than decapod larvae in the diet of postlarval lobsters. Despite the generally higher densities of copepods in the plankton, the overall frequency of occurrence of copepods and decapod larvae in the guts examined was not significantly different. However, the frequency of guts examined with copepods as newly ingested prey was greater than those with newly ingested decapod larvae. It is possible that the gut residency period of decapod larvae (e.g. appendages) may be greater than that for whole copepods. Evidently, a study of the feeding behavior of postlarval lobsters together with determination of the nutritional value and gut retention periods is needed to better elucidate the relative importance of these prey items. Nonetheless, results unequivocally show that while in the plankton, decapod larvae and copepods are major food items of postlarval Homarus americanus during all times of the day.

The fairly high incidence of fish eggs (commonly 2 to 4) and insect parts in the gut contents, compared to other prey groups, also suggests that these are regular prey items in the diet of postlarval lobsters. However, it was rare that these prey items were found as newly ingested. It is possible that insect parts and fish egg cases have long residence times in the gut of postlarval lobsters. If this were the case, the frequencies with which these prey groups were found probably overestimate their relative importance as prey items.

The high incidence of the most common and regular members of the plankton (i.e. copepods and decapod larvae) in the guts of postlarval lobsters suggests that postlarvae are opportunistic feeders. Likewise, the wide variety of prey groups including larvaceans, mysids and chaetognaths also suggest a non-selective feeding mode. However, the disproportionate frequency of occurrence of some prey groups in the gut contents relative to their abundance in the plankton suggests some degree of prey selectivity. For example, despite densities in the plankton comparable to decapod larvae, fish eggs were not as frequently found in the guts of postlarval lobsters. Furthermore, the higher incidence of adult and larger copepod species in the guts despite the generally much higher abundances of small copepods $(<1000 \mu \mathrm{m})$ particularly at night, strongly indicate preference for larger sized prey. The predominant species of calanoid copepods identified in the gut were adult Centropages spp., Acartia spp., Tortanus discaudatus and Temora longicornis which are among the largest copepod species in the area (Wilson 1932). Although species densities were not estimated in this study, visual assessment of the zooplankton samples (while counting the copepods from the bongo tow samples) suggested that the dominant species were the same as those previously reported by Deevey (1952a, b) and Frolander (1955). In view of this, Tortanus discaudatus presents an interesting case, since it is not one of the most abundant larger species in the area. Furthermore, most of the times that $T$. discaudatus was identified in the gut contents it was also newly ingested. Assuming that the gut residency period of copepod species are similar, the disproportionately high incidence of $T$. discaudatus despite its relative low abundance in the plankton, suggests that when present, this species may be selectively preyed upon by postlarval lobsters. Preference for crab megalopae which are large compared to most members of the plankton was even more evident from our observations in the laboratory that megalopae aggressively fend off postlarvae attacking them. Despite this, megalopae were the most common decapod larvae found in the guts examined. It is interesting to note that the genus Cancer was also found to be a frequently ingested prey item of benthic juvenile and adult Homarus americanus (Weiss 1970). Harding et al. (1983) also found larger plankton such as Cancer spp. zoea and megalopae, adult Centropages spp. and large gastropod larvae to be most frequently present in the guts of postlarval lobsters $(\mathrm{N}=16$ ) collected from St. Georges Bay. This evident preference for larger prey would suggest that while in the plankton, lobster postlarvae generally feed raptorially. This is in contrast to other feeding modes, such as suspension feeding, which has been suggested to be important for newly settled postlarvae (Lavalli \& Barshaw 1989).

\section{Feeding activity}

It is interesting to note that only 20 postlarvae collected from the field had empty guts. Of these, nearly half ( 9 individuals) were in molt stage $\mathrm{A}$. A total of 11 postlarvae in molt stage $A$ were caught; the 2 that had material in their foreguts indicate that feeding during this molt stage is possible although the incidence is low. A few hours immediately after ecdysis, 
postlarvae are unable to feed (pers. lab. obs.). It is therefore likely that the postlarvae in molt stage A which had empty guts were caught before they had a chance to feed. In the laboratory, we found postlarvae with completely empty guts after 6 to $12 \mathrm{~h}$ of food (i.e. live zooplankton) deprivation. The very low incidence of postlarvae with completely empty guts during the diel sampling periods indicate that postlarvae forage successfully throughout the day. It is therefore highly unlikely that a considerable number of postlarvae in the field die due to starvation.

Results indicate no difference in the feeding activity of postlarvae at different molt stages. This finding does not agree with the expected higher feeding activity at postmolt and intermolt inferred from the rapid accumulation of reserves in early molt stage $B$ to early $D_{0}$ during the postlarval instar (Sasaki et al. 1986). Other studies have found that the feeding activity of crustaceans change over the molt cycle. Weiss (1970) found that the stomach fullness of juvenile Homarus americanus declined through the molt cycle. He noted that the stomachs of most individuals at molt stage $\mathrm{D}_{2}$ were empty. Lipcius \& Herrnkind (1982) also noted the same for subadults of the spiny lobster Panulirus argus. Furthermore, feeding ceased completely during ecdysis. Only 3 postlarvae at the late molt stages $D_{2}$ and $D_{3}$ were collected during this study, and all 3 had guts that were more than half full. The low number of animals at the late premolt stage may be attributed to settlement during this period (Cobb et al. 1989). It is likely that reduced feeding activity during the postlarval instar occurs after settlement to the benthos, prior to ecdysis to the fifth stage. However, while in the plankton, there was no apparent difference in feeding activity due to the molt cycle.

The very high individual variability in relative gut fullness and the condition of gut contents suggest that postlarval lobsters feed asynchronously and intermittently. However, despite this variability, some feeding periodicity exists at the population level. The significantly higher incidence of postlarvae with newly ingested prey in their guts during the night 121:00, 24:00 and 03:00 h) was suggestive of higher feeding activity during this time. We recognize that this index of feeding periodicity may be biased if net-feeding occurred during the $10 \mathrm{~min}$ neuston tows. Harding (pers. comm.) placed 10 stage 1 larvae which were starved for $1 \mathrm{~d}$ (to clear their guts) in the cod-end of a standard ring net which was towed at about $3 \mathrm{~m}$ for $30 \mathrm{~min}$, and found that each had a complete fresh copepod in the foregut. In our study, we assumed that the probability of net-feeding occurring was the same during all the sampling periods and that the probability was low since the duration of the tows was only 10 min. Furthermore, it is reasonable to expect that net feeding would be less common in nature compared to the observation of Harding (pers. comm.) since the larvae in that experiment were starved and undoubtedly ravenous. Thus, the significant difference in the incidence of newly ingested prey found among time categories was unlikely to have been an artifact of netfeeding. Conversely, gut fullness was significantly lower at midnight and at 03:00 h. Other studies have suggested that ingestion may be affected by stomach fullness (e.g. Sainsbury 1986, Penry \& Jumars 1987). It is conceivable that ingestion ceases or decreases when maximum gut capacity is attained. Whether this is true for Homarus americanus needs further study.

The higher feeding activity at night may be attributed to the generally greater abundance of prey in the surface waters during this time. This was suggested by the significantly higher incidence of copepods as newly ingested prey during the night when this prey group was more abundant. Carlberg \& Van Olst (1976) found that the consumption rates of laboratory-reared postlarval lobsters increased with increasing prey densities (i.e. live adult brine shrimp Artemia salina). However, there is no information on the threshold level for this feeding response. The high feeding activity during the night also indicates that detection of prey is not primarily visually mediated. This is in contrast to suggestions based on the daytime observations of Cobb et al. (1983) from the field as well as those of Herrick (1911) in the laboratory. The mechanisms by which foraging is accomplished at night is unclear. From our observations in the laboratory, frozen adult brine shrimps as well as live megalopae were generally not captured until the postlarvae 'bumped' into them. This suggests that tactile stimulation is also necessary for prey capture in postlarval lobsters. We speculate that in the absence of visual perception, swimming would increase the probability of encountering a prey at night.

In summary, this study contributed various insights into the diet and feeding habits of postlarval Homarus americanus in nature. Clearly, while in the plankton postlarvae are raptorial feeders preferring larger sized prey, particularly decapod larvae and calanoid copepods. Moreover, the molt cycle had no apparent effect on the feeding activity during the planktonic phase of the postlarval instar. Despite the high variability among individuals, feeding activity was highest during the night. Furthermore, the low incidence of completely empty guts indicate that postlarvae forage successfully throughout the day in the nearshore waters of Block Island Sound.

Acknowledgements. We thank our colleagues at the Depart ment of Zoology at the University of Rhode Island for their assistance during field sampling, especially P. Rooney, S. Lamont and $\mathrm{M}$. Clancy. We are grateful to $\mathrm{K}$. Wishner who gave valuable advice and provided laboratory space and 
equipment to analyze the zooplankton samples. We are also indebted to 3 anonymous reviewers who gave constructive criticisms to improve this manuscript. Some funding for this work was provided by the Lerner Gray Fund for Marine Research of the American Museum of Natural History and the Sigma Xi grant-in-aid of research awarded to M.A.R.J. This paper is contribution No. 209 of the Marine Science Institute, University of the Philippines

\section{LITERATURE CITED}

Caddy, J. F., Campbell, A. (1986). Summary of session 9: summary of research recommendations. International workshop on lobster recruitment. Can. J. Fish. Aquat. Sci. 43: $2394-2396$

Carlberg, J. M., Van Olst, J. C. (1976). Brine shrimp (Artemia salina) consumption by the larval stages of the American lobster (Homarus americanus) in relation to food density and water temperature. Proc. Wld Maricut. Soc. 7: $379-289$

Carter, J. A., Steele, D. H. (1982). Stomach contents of immature lobsters (Homarus americanus) from Placentia Bay, Newfoundland. Can. J. Zool. 60: 337-347

Castell, J. D., Kean, J. C. (1986). Evaluation of the role of nutrition in lobster recruitment. Can. J. Fish. Aquat. Sci. 43: $2320-2327$

Cobb, J. S., Gulbrasen, T., Phillips, B. F., Wang, D., Syslo, M. (1983). Behavior and distribution of larval and early juvenile Homarus americanus. Can J. Fish. Aquat. Sci. 40: $2184-2188$

Cobb, J. S., Wang, D., Campbell, D. B. (1989). Timing of settlement of postlarval lobsters (Homarus americanus): field and laboratory evidence. J. crust. Biol. 9: 60-66

Deevey, G. B. (1952a). Quantity and composition of the zooplankton of Block Island Sound. Bull. Bingham oceanogr Coll. 13: 120-164

Deevey, G. B. (1952b). A survey of the zooplankton of Block Island Sound, 1943-1946. Bull. Bingham oceanogr. Coll. 13: $65-119$

Eagles, M. D., Aiken, D. E., Waddy, S. L. (1986). Influence of light and food on larval American lobsters, Homarus americanus. Can. J. Fish. Aquat. Sci. 43: 2303-310

Elner, R. W., Campbell, A. (1987). Natural diets of Homarus americanus from barren ground and macroalgal habitats off southwestern Nova Scotia, Canada. Mar. Ecol. Prog. Ser. 37: 131-140

Fogarty, M. J. (ed.). (1983). Distribution and relative abundance of the American lobster, (Homarus americanus) larvae. New England investigations during 1974-1979. NOAA natn. mar. Fish. Service - Spec. Sci. Rep. Fish.

Fogarty, M. J., Idione, J. S. (1986). Recruitment dynamics in an American lobster (Homarus americanus) population. Can. J. Fish. Aquat. Sci. 43: 2368-2376

Frolander, H. F. (1955). The biology of the zooplankton of the

This article was presented by C. Hudson, Halifax, N.S., Canada
Narragansett Bay area. Ph.D thesis, Brown Univ.

Haefner, P. A. (1990). Natural diet of Callinectes ornatus (Brachyura: Portunidae) in Bermuda. J. crust. Biol. 10: 236-246

Harding, G. C., Drinkwater, K. F., Vass, W. P. (1983). Factors influencing the size in American lobster (Homarus americanus) stocks along the Atlantic coast of Nova Scotia, Gulf of St. Lawrence, and Gulf of Maine: a new synthesis. Can. J. Fish. Aquat. Sci. 39: 1117-1129

Harding, G. C., Pringle, J. D., Vass, W. P., Pearre, S., Smith, S. J. (1987). Vertical distribution and daily movements of larval lobsters, Homarus americanus over Browns Bank, Nova Scotia. Mar. Ecol. Prog. Ser. 41:29-41

Herrick, F. H. (1911). Natural history of the American lobster. Bull. U.S. Fish Commn. 29: 147-408

Hughes, J. T., Mathiessen, G. C. (1962). Observations on the biology of the American lobster, Homarus americanus. Limnol. Oceanogr. 7: 414-421

Hyslop, E. J. (1980). Stomach content analysis - a review of methods and their application. J. Fish Biol. 17: 411-429

Lavalli, K. L., Barshaw, D. E. (1989). Post-larval American lobsters (Homarus americanus) living in burrows may be suspension feeding. Mar. Behav. Physiol. 15: 255-264

Lipcius, R. N., Herrnkind, W. F. (1982). Molt cycle alterations in behavior, feeding and diel rhythms of a decapod crustacean, the spiny lobster Panulirus argus. Mar. Biol. 68: 241-252

Penry, D. L., Jumars, P. A. (1987). Modeling animal guts as chemical reactors. Am. Nat. 129: 68-96

Phillips, B. F., Sastry, A. N. (1980). Larval ecology. In: Phillips, B. F., Cobb, J. S. (eds.) The biology and management of lobsters, Vol. 1. Academic Press, New York, p. 2-82

Sainsbury, K. J. (1986). Estimation of food consumption from field observations of fish feeding cycles. J. Fish Biol. 29: 23-36

Sasaki, G. C. (1984). Biochemical changes associated with embryonic and larval development in the American lobster Homarus americanus Milne Edwards. Ph.D thesis, Mass. Inst. Technol./Woods Hole Oceanogr. Inst. 84-8

Sasaki, G. C., Capuzzo, J. M., Biesiot, P. (1986). Nutritional and bioenergetic considerations in the development of the American lobster Homarus americanus. Can. J. Fish. Aquat. Sci. 43: 2311-2319

Scarratt, D. J. (1973). Abundance, survival and vertical and diurnal distribution of lobster larvae in Northumberland Strait, 1962-1963 and their relationship with commercial stocks. J. Fish. Res. Bd Can. 30: 1819-1824

Scheltema, R. S. (1986). On dispersal and planktonic larvae of benthic invertebrates: an eclectic overview and summary of problems. Bull. mar. Sci. 39: 290-322

Weiss, H. M. (1970). The diet and feeding behavior of the lobster, Homarus americanus, in Long Island Sound. Ph.D thesis, Univ. of Connecticut, Storrs

Williams, L. W. (1907). The stomach of the lobster and the food of the larval lobsters. A. Rep. R.I. Comm. Inland Fish. 37: $153-180$

Wilson, C. B. (1932). The copepods of the Woods Hole Region Massachusetts. Smithson. Inst. Bull. 158

Manuscript first received: November, 14, 1991

Revised version accepted: June 23, 1992 